\title{
Evaluation of Bait Usage in the KwaZulu-Natal Linefishery, South Africa
}

\author{
Pierre Pradervand and Sean Fennessy \\ Oceanographic Research Institute, PO Box 10712, Marine Parade, Durban, 4051, South Africa
}

\begin{abstract}
Keywords: Bait, linefishery, recreational fishing, commercial fishing, KwaZulu-Natal, species composition, resource management

Abstract-Bait usage in the KwaZulu-Natal recreational and commercial linefishery was assessed using historic fisher-derived data and current sales records of bait providers. Total bait usage in two of the three linefishery components in KZN was estimated to range from 928 - 3,400 tonnes per year. A total of 39 different bait types were identified to have been used in the KZN linefishery, and sardines (Sardinops sagax) sourced from the South African purse-seine fleet, were the most important (used in $>79 \%$ of fisher outings, $>86 \%$ of bait sold by wholesalers). Conservation implications of bait usage in KZN are discussed, and recommendations for improved management are presented.
\end{abstract}

\section{INTRODUCTION}

Fishing with rod, hook and line (linefishing) is a popular pursuit along the $560 \mathrm{~km}$ coastline of the province of KwaZulu-Natal (KZN) in South Africa (Brouwer et al., 1997; Penney et al., 1999). The linefishery is comprised of three components, namely marine offshore boat, marine shore and estuarine (shore- and boat-based), participants in which can be designated as falling into one of three linefishing sectors (recreational, commercial and subsistence). Each of these sectors is regulated by national legislation under the Marine Living Resources Act (No. 18 of 1998) and each is subject to specific management regulations. Unlike other coastal provinces in South Africa, custodianship of marine resources in KZN has been vested in the provincial nature conservation agency, namely Ezemvelo KZN Wildlife (ex-Natal Parks Board), which accordingly is responsible for implementing the various requirements of the Act. Prior to this study, limited data existed on bait usage in the South African linefishery. Several component- specific studies on sectors of the linefishery (Mann et al., 1997; Sauer et al., 1997; Mann et al., 2002; Pradervand et al., 2003; Everett 2005; Jairam 2005) collected data on bait as an adjunct to their respective primary objectives, but no studies have focussed specifically on assessing bait usage for all components of the linefishery on a provincial or national level. The primary objective of this study was to provide baseline quantitative data on present bait usage in the KZN linefishery on a provincial basis based on pre-existing data for each component (i.e. offshore, shore and estuarine) and from recent surveys of bait providers. The secondary objective was to identify and elucidate conservation and fisheries management issues arising from bait usage in the KZN linefishery, and to make recommendations accordingly.

\section{MATERIALS AND METHODS}

Two approaches were used to achieve the objectives of this study, namely a review of existing data and a survey of current bait providers. 


\section{Review of existing data}

All available formally- and informally-published data sources on bait usage in the KZN linefishery were investigated for information on the extent of bait usage (i.e. what proportion of outings use bait), bait choice (i.e. what type of baits were used) and monetary expenditure on bait by fishers. As each component of the KZN linefishery is largely unique in its methodology, areas of operation and species targeted (van der Elst, 1989), all historic data were presented on a per-component basis (i.e. offshore, shore and estuary). The following is a description of each data source investigated, and of the respective data contributed to the study.

\section{Offshore linefishery}

1. National Marine Linefish System. This is a large-scale on-going national government fisheries database, which includes the monitoring of recreational offshore boat fishers at popular launch sites (Penney et al., 1997; Pradervand \& Govender 1999). The source of its observer-based data in KZN is compliance-orientated fisher inspections by Ezemvelo KZN Wildlife (EKZNW). The database of catch and effort information was analysed for trends in the proportion of fish specifically landed by recreational offshore fishers for subsequent use as bait (baitfish). Data from the province's four boat launch sites with the highest monitoring effort (St Lucia, Richards Bay, Durban, Shelly Beach, Figure 1) were examined for the period 1986-2004. Baitfish were defined as all mackerels and scads, redeye sardine, cutlass fish, garfish, wolfherring, pinkies and strepies (Table 1).

2. Boat Launch Site Monitoring System. A recently-initiated (2004) provincial government monitoring programme for boat launch sites along the KZN coast (Celliers et al., 2004; Pradervand et al., 2006). This system's database, of voluntarily-submitted information (fisher-dependent), was analysed for trends in reported catches of baitfish species by recreational offshore boat fishers during the period February 2004 - May 2005. Baitfish were defined as above.
3. KZN charter boat fishery. A short-term study (2003/2004) assessed the extent and impacts of the KZN offshore charter boat fishery (Pradervand, 2005). This study only recorded the average expenditure on bait by charter operators, and did not formally enquire as to the extent of bait usage (i.e. what proportion of charter outings used bait) or as to the bait types used.

4. National linefish survey. The only survey conducted to date on the South African shore and offshore boat linefishery on a national scale, but which excluded estuarine fisheries (Mann et al., 1997; Sauer et al., 1997). The KZN recreational and commercial offshore boat fishery was surveyed from 1994 - 1995, and included the extent of bait usage and type of bait used by offshore fishers.

5. Richards Bay linefishery. The recreational offshore boat fishery operating from the Richards Bay harbour was surveyed from 2002 to 2004, and the commercial offshore boat fishery was surveyed from 2001 onwards (Jairam, 2005). The study provided information on extent and type of bait used by these fishers, as well as expenditure on bait.

\section{Shore linefishery}

National linefish survey. This province-wide survey of the KZN shore fishery was performed concurrently with the survey of the province's offshore boat fishery (1994 - 1995 - see above), and collected information on the extent and type of bait used by shore fishers (Mann et al., 1997; Brouwer et al., 1997).

\section{Estuarine linefishery}

1. St Lucia estuarine fishery. A 1-year survey of this fishery was performed in 1994, and collected information on extent of bait usage and expenditure on bait by estuarine fishers (Mann et al., 2002).

2. Durban harbour and Mgeni estuary fisheries. This study of two urban estuarine fisheries was conducted in 2000 , and provided data on bait choice by estuarine fishers and source of baits (Pradervand et al., 2003). 


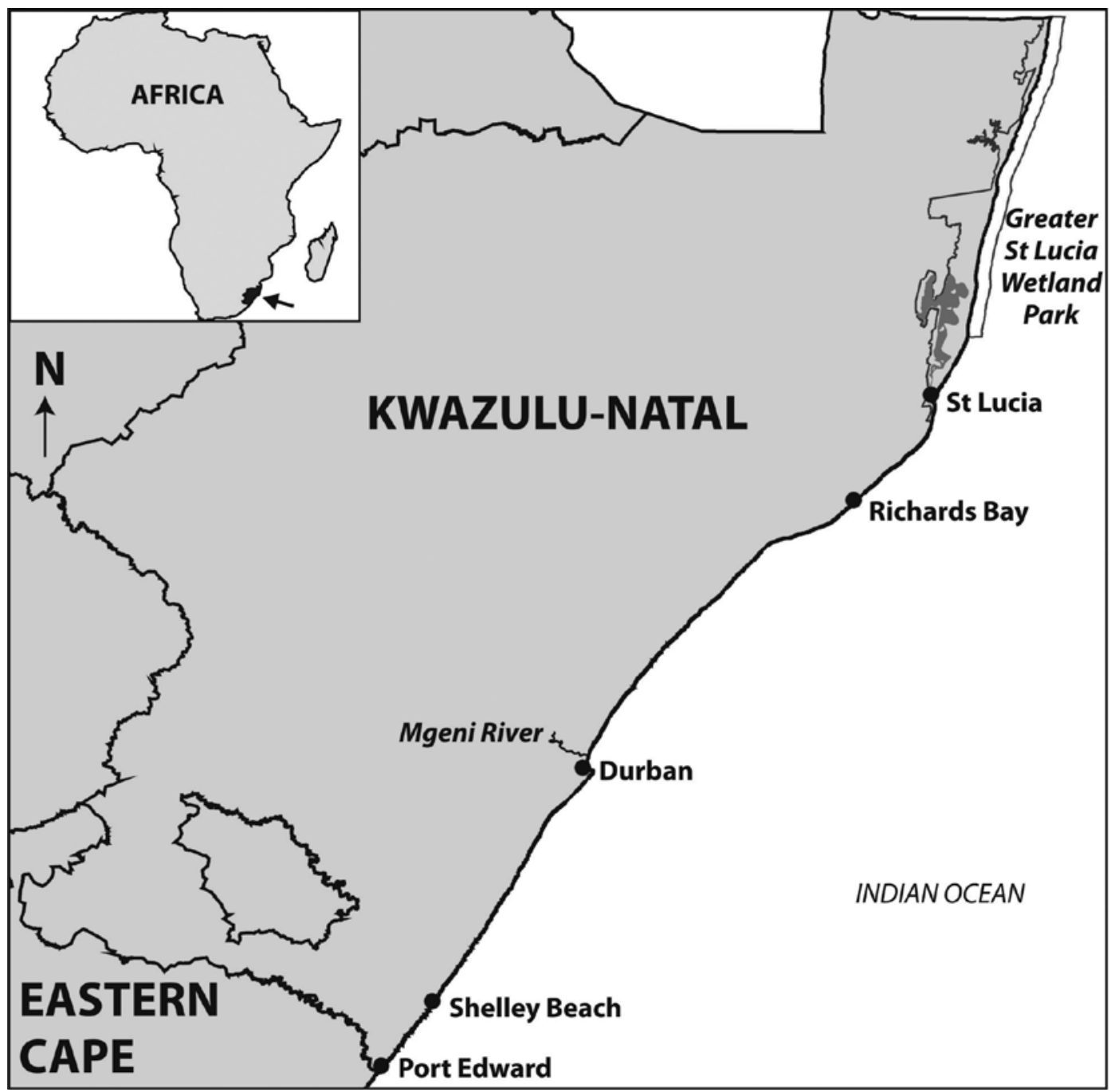

Fig. 1. Map showing location of place names mentioned in text

3. Richards Bay linefishery. The shore- and boatbased fishery within the Richards Bay harbour was surveyed from 2001 to 2003 , providing information on the extent of bait usage, choice of baits and expenditure on bait by estuarine fishers (Everett, 2005, Everett \& Fennessy, 2007, Beckley et al., 2008).

\section{Survey of bait providers}

In order to gauge current levels of bait usage, specialist bait retailers (i.e. fishing tackle outlets) in KZN's largest coastal city (Durban) were identified from the 2004/05 Durban telephone directory and the media (i.e. newspaper, advertisements in fishing magazines, etc.) and interviewed during 2005 (on-site or by telephone) for information on type, quantity and source of bait sold. Further retail outlets within the Durban city limits which could potentially sell bait (potential non-specialist outlets for bait e.g. general dealers, cafés, chain stores, etc.) were visited, and further such outlets within the greater Durban area were contacted by telephone to determine the proportion of outlets offering bait, and the type, quantity and source of bait sold. These outlets were also randomly selected from the telephone directory and the media. 
Bait wholesalers identified by the aforementioned bait retailers were interviewed (on-site or by telephone) to determine the total annual quantities of the main bait products that they sold.

Because of inconsistencies in the use of common names of bait types and the inability of retailers and wholesalers to describe their baits to a species level or to provide samples of all bait types, all baits mentioned in the text are identified to at least family level (Table 1). For similar reasons, several baits were grouped into broad categories. For example, squid incorporates chokka (Loligo vulgaris reynaudii), potta (Ommastrephidae) and Tugela squid (Loligo sp.), and swimming prawn includes both white prawn (Penaeus indicus) and pink prawn (Haliporoides triarthrus). Only baits that were sold to the KZN linefishery by wholesalers and retailers were considered in this study, and sales to longliners operating in KZN waters were excluded, as were all baits which were exported out of the province.

\section{Calculation of total bait usage}

The total annual quantity of the two main bait types (sardine and squid) presently used in the shore and recreational and commercial offshore boat sectors of the KZN linefishery was estimated from bait usage information from previous studies. Most of these studies collected data on bait usage in terms of expenditure on bait per outing, and these figures were incremented at an annual inflationary rate of $6 \%$ to bring them into line with 2005 prices. These were then converted to quantities (i.e. $\mathrm{kg}$ ) using present-day prices of baits obtained in the current survey of bait providers (i.e. bait expenditure per outing (expressed in 2005 terms) divided by average current retail price of bait type per $\mathrm{kg}$ ).

Total current effort estimates for the shore and offshore boat fishing sectors were derived from the National Marine Linefish System and the Boat Launch Site Monitoring System respectively. As no estimate of total effort for the provincial estuarine linefishery exists, this sector was omitted from the calculation.

The quantity $(\mathrm{kg})$ of sardine and squid used per outing in the shore and recreational and commercial offshore linefishery sectors was estimated as follows:

$$
a=(b \times c) \times d
$$

where $\mathrm{a}=$ total quantity $(\mathrm{kg})$ of specific bait type used per sector per annum

$b=$ total number of outings for fishery sector

$\mathrm{c}=$ proportion of total outings that use specific bait type

$\mathrm{d}=$ quantity $(\mathrm{kg})$ of bait type used per outing $(d=e / f)$, where

$\mathrm{e}=$ bait expenditure per outing (extrapolated to current value at $6 \%$ p.a.)

$\mathrm{f}=$ average current retail price of bait type per $\mathrm{kg}$.

\section{RESULTS}

\section{Review of existing data}

All relevant data on bait usage that were gleaned from existing data sources and utilised in the present study are summarised in Table 2 , and presented by sector below.

\section{Offshore linefishery}

1. National Marine Linefish System. Examination of the contribution of baitfish to landed catches indicated that such species were only of importance at the Durban launch site (the most commonly used launch site in the province). The proportion of baitfish species (especially redeye sardine and chub mackerel) landed at this site increased seven-fold from the period 1986 - 1996 to the period 1997 - 2003 (Oceanographic Research Institute, unpublished data).

2. Boat Launch Site Monitoring System. The analysis of catch returns from the Durban launch site indicated that baitfish comprised a higher proportion of the catch landed at this site than at any of the other 35 launch sites participating in this monitoring programme (Oceanographic Research Institute, unpublished data).

3. KZN charter boat fishery. Informal observations made during this study suggest that bait usage in this fishery is high ( $>85 \%$ of outings). Further qualitative observations were made of the frequent usage that was being made of freshly-caught linefish (mostly sub-legal sized or undesirable specimens) as sliced or live 
Table 1: Identification of all bait types mentioned in text presented in terms of reported baits sold by bait wholesalers and retailers and those reported to have been used by fishers (previous studies). The full identify of baits not observed was inferred if the authors were sufficiently confident in this regard. Bait types are arranged alphabetically under Family name

Bait types sold by surveyed wholesalers and retailers

[ ${ }^{1}$ observed, ${ }^{2}$ not observed]

\begin{tabular}{|c|c|c|}
\hline Common name & Family & Scientific name \\
\hline Sardines $^{1}$ & Clupeidae & Sardinops sagax \\
\hline Redeye sardines $^{1}$ & Clupeidae & Etrumeus teres \\
\hline \multicolumn{3}{|l|}{ Squid } \\
\hline$\left(\operatorname{chokka}^{1}\right)$ & Loliginidae & Loligo vulgaris reynaudii \\
\hline$\left(\right.$ potta $\left.^{2}\right)$ & Full identity not inferable & Full identity not inferable \\
\hline (Tugela squid ${ }^{2}$ ) & Full identity not inferable & Full identity not inferable \\
\hline Mullet $^{2}$ & Mugilidae & Full identity not inferable \\
\hline Langoustines $^{2}$ & Nephropidae & Metanephrops mozambicus \\
\hline \multicolumn{3}{|l|}{ Swimming prawn ${ }^{2}$} \\
\hline (white prawn) & Penaeidae & Penaeus indicus \\
\hline (pink prawn) & Penaeidae & Haliporoides triarthrus \\
\hline Chub mackerel ${ }^{1}$ & Scombridae & Scomber japonicus \\
\hline Eastern little tuna $^{1}$ & Scombridae & Euthynnus affinis \\
\hline \multicolumn{3}{|l|}{ Bonito $^{2}$} \\
\hline (Oceanic bonito) & Scombridae & Katsuwonus pelamis \\
\hline (Striped bonito) & Scombridae & Sarda orientalis \\
\hline (Bonito) & Scombridae & Sarda sarda \\
\hline Indian mackerel $^{1}$ & Scombridae & Rastrelliger kanagurta \\
\hline French mackerel $^{2}$ & Scombridae & Full identity not inferable \\
\hline Tuna pieces $^{2}$ & Scombridae & Full identity not inferable \\
\hline Japanese mackerel $^{1}$ & Scomberesocidae & Cololabis spp. \& Scomberesox spp. \\
\hline Cutlass fish ${ }^{1}$ & Trichiuridae & Trichiurus lepturus \\
\hline Octopus $^{2}$ & Full identity not inferable & Full identity not inferable \\
\hline
\end{tabular}

Bait types recorded in previous studies

[the identity of these baits was not verified]

\begin{tabular}{|c|c|c|}
\hline Common name & Family & Scientific name \\
\hline \multicolumn{3}{|l|}{ Garfish } \\
\hline (barred needlefish) & Belonidae & Ablennes hians \\
\hline (yellowfin needlefish) & Belonidae & Strongylura leira \\
\hline Sand prawn & Callianassidae & Callianassa kraussi \\
\hline \multicolumn{3}{|l|}{ Scad } \\
\hline (Slender scad) & Carangidae & Decapterus macrosoma \\
\hline (Shrimp scad) & Carangidae & Alepes djedaba \\
\hline (Torpedo scad) & Carangidae & Megalaspis cordyla \\
\hline (Maasbanker) & Carangidae & Trachurus spp. \\
\hline Wolfherring & Chirocentridae & Chirocentrus dorab \\
\hline Redeye sardines & Clupeidae & Etrumeus spp. \\
\hline Pinky & Haemulidae & Pomadasys olivaceum \\
\hline \multirow[t]{2}{*}{ Sea lice } & Hippidae & Emerita sp. \\
\hline & Hippidae & Hippa ovalis \\
\hline \multicolumn{3}{|l|}{ Prawn } \\
\hline (white prawn) & Penaeidae & Fenneropenaeus indicus \\
\hline \multicolumn{3}{|l|}{ Mackerel } \\
\hline (chub mackere ${ }^{1}$ ) & Scombridae & Scomber japonicus \\
\hline$\left(\right.$ Indian mackere $\left.{ }^{1}\right)$ & Scombridae & Rastrelliger kanagurta \\
\hline Strepie & Sparidae & Sarpa salpa \\
\hline \multicolumn{3}{|l|}{ Prawn } \\
\hline (pink prawn) & Solenoceridae & Haliporoides triarthrus \\
\hline Cutlass fish & Trichiuridae & Trichiurus lepturus \\
\hline
\end{tabular}




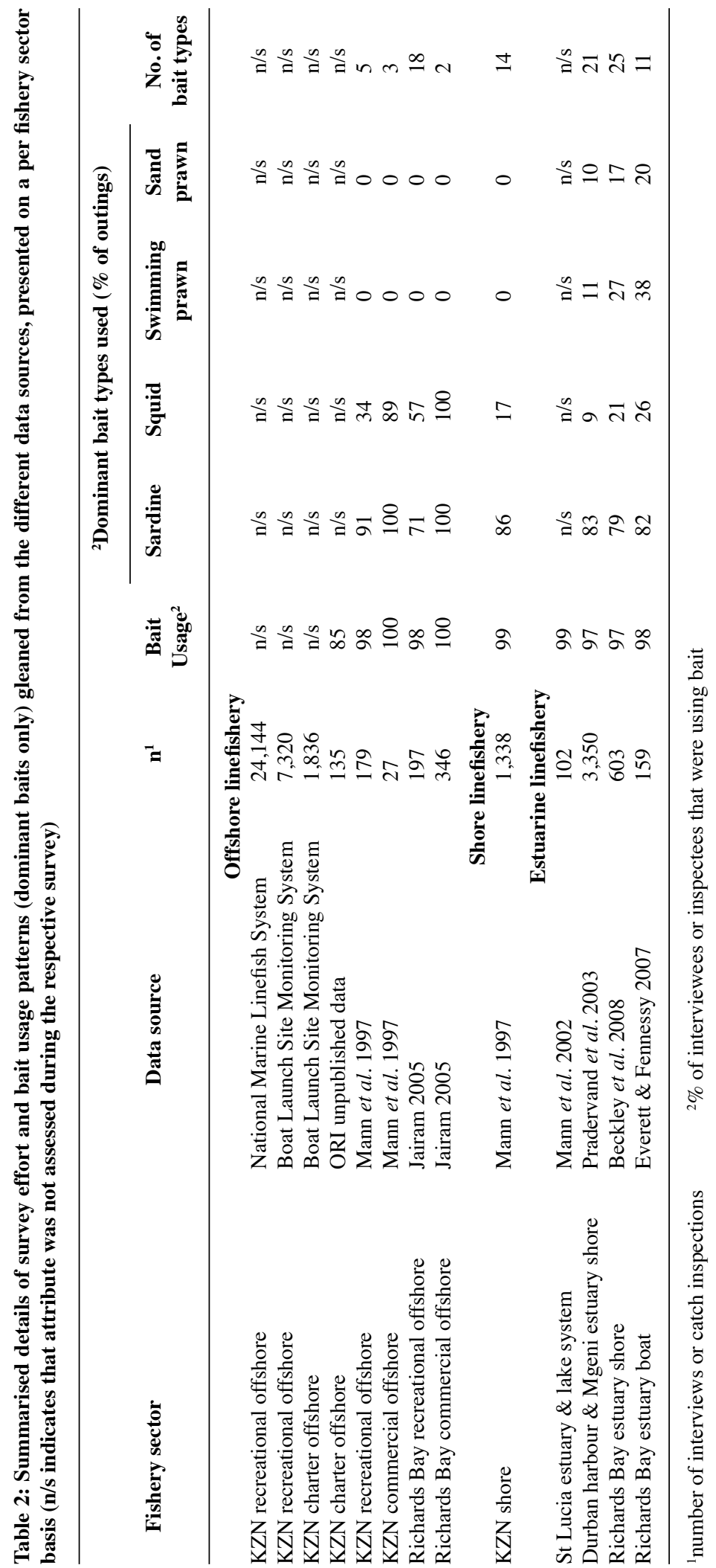


baits. The active targeting of baitfish species during charter outings was estimated as being comparatively low ( $<10 \%$ of outings).

4. National linefish survey. The results showed high usage levels of bait ( $>93 \%$ of surveyed outings), and that sardines and squid were the most commonly-used baits.

5. Richards Bay linefishery. The results from these surveys indicated that bait was used in $>97 \%$ of outings, and that sardine and squid were the dominant bait types.

\section{Shore linefishery}

National linefish survey. This survey showed that bait usage in the province's shore fishery was also high ( $99 \%$ of surveyed outings), and that sardines and squid were the most commonly-used baits.

\subsection{Estuarine linefishery}

1. St Lucia estuarine fishery. The study showed a high degree of bait usage (99\% of surveyed outings).

2. Durban harbour and Mgeni estuary fisheries. Of the shore-based fishers inspected in the Durban harbour and along the Mgeni estuary $97 \%$ used bait. Sardine, bread, swimming prawn, sand prawn and squid were the most commonlyused baits. Investigation of the source of the commonly-used baits revealed that $79 \%$ of interviewees purchased sardines from nonspecialist shops (i.e. large retail chain stores, general dealers, corner cafés, garage shops, etc.). Only $16 \%$ of interviewees indicated that they bought their sardines from specialist bait outlets (i.e. fishing shops). Less than $5 \%$ of interviewees reported obtaining sardines from the annual "sardine run" - either through selfcollection or purchasing from seine-netters. The "sardine run" is an annual phenomenon in which large numbers of sardines from waters off the adjacent Eastern Cape Province migrate into KZN coastal waters during winter - often becoming accessible to shore-based catching methods such as seine nets, cast nets, scoop nets, etc. (Beckley \& van der Lingen, 1999). Squid was also purchased primarily from nonspecialist shops (77\% of interviewees) and sand prawns were mostly self-collected $(67 \%$ of interviewees).
3. Richards Bay linefishery. The results from this survey showed bait usage in $>97 \%$ of outings, and indicated that sardine, squid, swimming prawn and sand prawn were the most commonly used baits within the harbour.

\section{Survey of bait providers}

Only five of the ten specialist bait retailers listed in the telephone directory were willing to participate in the survey. A total of 18 bait types were offered for sale by these retailers, but only three retailers offered more than 10 types of baits. Sardines, squid and Japanese mackerel were stocked by all the surveyed retailers, while swimming prawn, octopus and redeye sardine were also offered by three of the five surveyed retailers. All other baits contributed far less. Reported total annual sales of bait varied considerably between different retailers, ranging from 8 to 49 tonnes per year. Sardine made up most of the weight of the cumulative sales of the five retailers, followed by redeye sardine, chub mackerel and squid (Table 3). All of the specialist bait retailers indicated that they obtained their baits from one or more of five bait wholesalers, with the exception of redeye sardines, chub mackerel, eastern little tuna and Indian mackerel which were obtained primarily from local recreational offshore boat fishers.

The majority $(n=128)$ of the 159 non-specialist potential bait outlets that were investigated did not sell bait (Table 4). Those that did so, sold sardine exclusively, with the exception of three outlets which also offered swimming prawn and squid. Although the 31 interviewees that did sell bait were unable or unwilling to provide annual sales figures, the cumulative quantity of bait sold by these retailers may be substantial given the propensity of fishers to purchase their bait from non-specialist bait retailers (as identified in the Durban harbour and Mgeni estuary study - see section 1.3.2). With respect to the source of baits sold by these retailers, half $(n=15)$ indicated that they obtained the products from the same wholesalers utilised by specialist bait retailers. The remainder were unable or unwilling to disclose the source of their baits.

Only five bait wholesalers were identified in $\mathrm{KZN}$, and three of these were willing or able to provide estimates of the total annual quantity of 
Table 3: Annual quantity (kg) of main bait types reported sold by specialist bait retailers

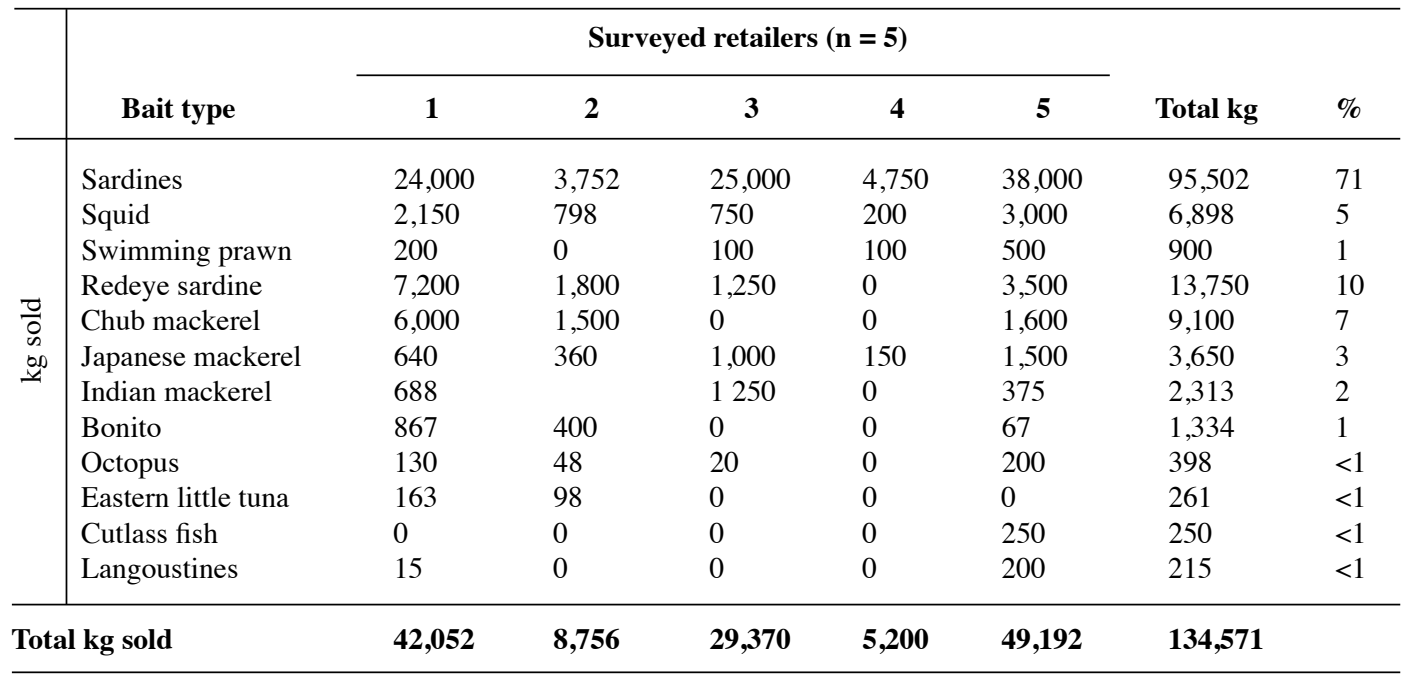

Table 4: Results of survey of potential non-specialist bait retailers

\begin{tabular}{lccc}
\hline & \multicolumn{3}{c}{ Site survey } \\
\cline { 2 - 4 } Type of retailer & $\begin{array}{c}\text { No. } \\
\text { contacted }\end{array}$ & $\begin{array}{c}\text { No. } \\
\text { selling } \\
\text { bait }\end{array}$ & $\begin{array}{c}\text { No. } \\
\text { not selling } \\
\text { bait }\end{array}$ \\
\hline Café & 27 & 5 & 22 \\
Chain store & 4 & 2 & 2 \\
Garage shop & 4 & 1 & 3 \\
Phone survey & & 12 & 59 \\
Café & 71 & 11 & 42 \\
Chain store & 53 & $\mathbf{3 1}$ & $\mathbf{1 2 8}$ \\
\hline Total & $\mathbf{1 5 9}$ &
\end{tabular}

dominant bait types sold (Table 5). The other two wholesalers only gave an overall estimate of total bait sales i.e. no details of sales per bait type. Of the 23 different bait types reported sold by wholesalers, sardines (81\%) and squid (10\%) were the two most important baits in terms of annual quantity (by weight) sold. Less important baits for which no sales figures were given included bonito, Indian mackerel, cutlass fish and maasbanker. The total quantity of bait sold by these top five wholesalers to retailers in KZN amounted to some 928 tonnes per year. All of the bait wholesalers indicated that they obtained the majority of the sardines from outside $\mathrm{KZN}$ - primarily from the industrial purse-seine fishery in the Eastern and Western Cape, and most of their larger squid (chokka) was also obtained from the Eastern Cape. Smaller squid species such as potta squid and Tugela squid were obtained from within KZN. Other bait species were imported from a range of sources from outside KZN.

\section{Calculation of total bait usage}

Based on data from previous studies, total current usage of sardine and squid in the KZN shore and recreational and commercial offshore boat linefishery was estimated at 3,431 tonnes p.a., of which sardine comprised $96 \%$ (Table 6). The shore fishery accounted for an estimated $94 \%$ of overall bait usage in these two linefishery sectors. It should be noted that, for the shore fishery, these estimations are largely based on studies conducted during the period 1994-1995, which is prior to redeye sardines and other small pelagic fish species becoming a popular bait option for this sector of the linefishery (see below). Consequently, the estimation of total bait usage in the KZN shore and recreational and commercial offshore boat linefishery excludes these species.

\section{DISCUSSION AND CONCLUSION}

Based on the previous studies reviewed here, a cumulative total of 39 different bait types have been used in the various components of the KZN linefishery to date. Interviews conducted during this study, however, recorded a total of only 23 
Table 5: Total annual quantity (kg) of the dominant bait types sold by KZN wholesalers

\begin{tabular}{|c|c|c|c|c|c|}
\hline \multirow[b]{2}{*}{ Bait types } & \multicolumn{5}{|c|}{ Surveyed wholesalers $(n=5)$} \\
\hline & 1 & 2 & 3 & 4 & 5 \\
\hline Sardine & 140,000 & 120,000 & 250,240 & $*$ & $*$ \\
\hline Japanese mackerel & 6,000 & 6,000 & 12,000 & $*$ & $*$ \\
\hline Squid & 0 & 3,600 & 57,000 & $*$ & $*$ \\
\hline Chub mackerel & 0 & 1,800 & 10,400 & $*$ & $*$ \\
\hline French mackerel & 0 & 2,400 & 0 & $*$ & $*$ \\
\hline Redeye sardine & 0 & 0 & 2,600 & $*$ & $*$ \\
\hline Swimming prawn & 0 & 4,000 & 10,000 & $*$ & $*$ \\
\hline Eastern little tuna & 0 & 0 & 100 & $*$ & $*$ \\
\hline Tuna pieces & 0 & 0 & 100 & $*$ & $*$ \\
\hline Mullet & 0 & 0 & 800 & $*$ & $*$ \\
\hline Octopus & 0 & 0 & 600 & $*$ & $*$ \\
\hline Total & 146,000 & 137,800 & 343,840 & 180,000 & 120,000 \\
\hline
\end{tabular}

*sales per bait type not provided

Table 6: Annual quantity (kg) of the two most popular bait types used in the shore and boat linefisheries of KZN based on bait usage patterns previously published. Values rounded off to nearest $100 \mathrm{~kg}$. Overall percentage contribution of the bait types is given in parentheses

\begin{tabular}{lcrrr}
\hline \multicolumn{1}{c}{ Fishery sector } & Sardine & Squid & Total & \% \\
\hline Shore & $3,149,900$ & 86,400 & $3,236,300$ & 94 \\
Recreational offshore boat & 129,600 & 24,800 & 154,400 & 5 \\
Commercial offshore boat & 24,300 & 16,200 & 40,500 & 1 \\
\hline Total & $\mathbf{3 , 3 0 3 , 8 0 0 ( 9 6 )}$ & $\mathbf{1 2 7 , 4 0 0}(\mathbf{4 )}$ & $\mathbf{3 , 4 3 1 , 2 0 0}$ \\
\hline
\end{tabular}

bait types offered by wholesalers and 19 types by retailers - somewhat less than the total range reportedly used by fishers. This discrepancy is expected, given the reported use of baits by fishers which are not commercially available from bait retailers and wholesalers (e.g. self-collected bait organisms such as sand prawn).

The current importance of respective bait types in the KZN linefishery, as reported by bait providers in this study, differed somewhat from the importance of these baits in earlier studies. Previously, the most important baits in most of the KZN linefishery components were sardine and squid (Mann et al., 1997; Jairam 2005). Presently, however, species such as redeye sardine, chub mackerel and Japanese mackerel also constitute an important component of baits used in the linefishery. Although sardines are still the most important bait in KZN, redeye sardines were the second-most important bait sold by four of the five specialist retailers surveyed in the present study, whilst chub mackerel were the third most important species for two of the five surveyed specialist retailers, followed by squid and Japanese mackerel. The discrepancy in the importance of dominant baits between the previous studies and the present study is attributable to an increased use of redeye sardine, chub mackerel and Japanese mackerel in the KZN linefishery from 1997 onwards (Barry Wareham, Basil Manning Fishing Tackle, pers. comm.). This change in bait preference over time is regarded as a consequence of improved fisher knowledge and improved gear technology, particularly in the shore fishery (Pradervand \& Govender, 2003; Pradervand, 2004; Pradervand et al. 2007).

Current total bait usage in the KZN shore and recreational and commercial offshore boat linefishery components, based on earlier surveys of fishers, is estimated at about 3,400 tonnes, substantially higher than the 928 tonnes estimated 
to be brought into KZN by wholesalers. Ostensibly, bait usage in the whole KZN linefishery (all sector and components) will be even higher, as the figure of 3,400 tonnes excludes bait usage in the KZN subsistence linefishing sector and in the estuarine linefishery, estimates of which could not be made as there are currently no estimates for total effort in these sectors. Bait usage in the $\mathrm{KZN}$ estuarine linefishery is probably high, given the relative popularity of estuarine fishing in the adjacent Eastern Cape Province (Pradervand \& Baird, 2000) and the large number of estuaries in KZN (73 estuaries) (Begg, 1978). Bait usage in the subsistence linefishery is, however, probably not high, as the number of participants is regarded as low (Mann et al., 1997), and their economic status (Branch et al., 2002) probably precludes the purchasing of baits (i.e. these fishers mainly collect their baits).

Accounting for the discrepancy between the above two estimates of total bait usage is not straightforward. There is no reason to believe that the figures provided by the wholesalers are substantially incorrect. Also, bait supply to the province other than via the five main wholesalers is regarded as minimal, as no retailers indicated sources other than the five wholesalers approached for annual sales figures. Consequently, the estimate based on sales by wholesalers ( 928 tonnes) is the more realistic estimate of current total usage of the most popular baits (sardines and squid) in the KZN linefishery, and the estimate based on fisher surveys $(3,400$ tonnes $)$ is regarded as an over-estimate for several reasons. Firstly, the bait expenditure per outing values provided by fishers are regarded as exaggerated. Fishers generally retain unused bait from one outing for use in subsequent outings, so the figures provided by fishers in fact reflect expenditure on several outings (Oceanographic Research Institute, unpublished data). Secondly, the increased availability in recent years of individuallypacked baits (e.g. IQF sardine - individually quick frozen sardine) has further promoted this rationalisation of bait use, which would reduce expenditure on bait, and hence artificially inflate the per-outing estimate of bait usage. Thirdly, the total effort estimate used in the calculation of total bait usage in the shore fishery was derived from compliance-orientated creel surveys undertaken by
Ezemvelo KZN Wildlife staff. These surveys are not undertaken in a statistically rigorous manner, and consequently the data are prone to various biases (Pradervand \& Govender, 1999).

Although the elucidation of conservation and management issues relating to bait usage was an initial objective of the study, limited taxonomic information on several bait types sold by retailers and wholesalers precluded meeting this objective for the lesser-important baits. Poor identification of bait arises from inadequate legislation which stipulates that only foreign imports of bait into KZN require full declaration of taxonomic identity and origin. All baits sourced overseas and imported indirectly to KZN (e.g. via wholesalers in the Cape) require only an invoice indicating the secondary source of the baits (i.e. the wholesaler in the Cape), with no need for details regarding the taxonomy or primary origin of the baits (e.g. Argentina, California etc.) (Regulatiion 27(1) (e) of the Marine Living Resources Act, No. 18 of 1998). Consequently, it was often difficult to fully identify overseas-sourced baits that were subsequently transferred to KZN via the Western Cape, and it was almost impossible to accurately determine their primary origin. Furthermore, it was not posssible to identify baits that were not examined during the on-site survey, and the identity of baits from the telephone survey as provided by bait sellers could not be verified. The validity of such identifications is potentially compromised by bait sellers who referred to baits only by their common names, which were often applied to several species.

It was, however, possible to elucidate on the conservation and management issues relating to some of the baits which were fully identifiable. The sardine and chokka squid used in the KZN linefishery are mostly sourced by KZN wholesalers directly from formal commercial fisheries in the Western and Eastern Cape Provinces, respectively (Cochrane et al., 1998). As both these fisheries are well-managed (De Oliveira et al. 1998, Sauer et al. 2003), and contribute only a small proportion $(<10 \%)$ of their respective annual catches to the bait industry (Sauer et al., 2003; Augustyn et al,. 1992), the use of sardine and squid in the KZN linefishery is not regarded as presenting a management or conservation problem. However, the increased use of several species of locally-harvested small 
pelagic fishes such as redeye sardine, chub mackerel, Indian mackerel, eastern little tuna and bonitos in the KZN linefishery subsequent to 1996 potentially requires management. These species, which are highly-desired by shore fishers as bait, are mostly sourced illegally by retailers directly from recreational offshore boat fishers, as current legal sources of such species, notably the KZN traditional commercial linefishery and the industrial purse-seine fishery in the Western and Eastern Cape Provinces, do not satisfy the demand. Commercial linefishers do not normally target small pelagics, as they provide less financial reward than their normal target of reef-associated demersal species (Mann et al., 1997), and the industrial purse-seine fishery seldom catches small pelagic baitfish such as redeye sardines in appreciable numbers (Roel \& Armstrong, 1991). Furthermore, purse-seined fish are often of an inferior quality to line-caught fish and are frequently unsuitable for bait purposes (Barry Wareham, Basil Manning Fishing Tackle, pers. comm.).

Bait retailers and wholesalers in KZN have attempted to secure suitable legal sources of redeye sardines for the Province's bait trade via applications to the national fisheries department (Marine \& Coastal Management) for permission to operate various small-scale commercial fisheries directed at redeye sardines and other small pelagic species. To date, only one experimental purse-seine license for small pelagics has been granted in $\mathrm{KZN}$, and this fishery has yet to commence operations. A similar situation exists in KZN with regards to sand prawns, whereby the only legal source of this bait (i.e. self-collection under permit) has not satisfied demand, leading to the creation of a long-standing illegal trade in the species (Rob Broker, Ezemvelo KZN Wildlife, pers. comm.). The small-scale commercialisation of sand prawns in KZN was proposed to Marine \& Coastal Management over a decade ago (Tomalin et al., 1993; Tomalin et al., 1996), but little has been done to make this fishery a reality.

The primary recommendations from the present study relate to the issue of commercialising redeye sardines (and other small pelagic fish species) and sand prawns. Given the extent of the illegal trade in these organisms, there is a strong market demand for both species in KZN. As outlined in the Marine Living Resources Act, Marine \& Coastal Management should assess the potential for commercialisation of fisheries for these organisms - both from a stock and economic viability perspective. If biologically sustainable, formalisation of what are already de facto commercial fisheries is recommended. Provided it is sustainable and manageable, local fisheries managers (Ezemvelo KZN Wildlife) support the implementation of small-scale commercial fisheries for both sand prawns (Callianassa kraussii) and the above-mentioned small pelagic fish species in KZN (Rob Broker, Ezemvelo KZN Wildlife, pers. comm.).

It is also recommended, given the difficulties encountered during the study in trying to determine the scientific identity and primary origin of bait sold by bait wholesalers and retailers in KZN, that these details accompany the bait until point of final sale, regardless of whether the bait originates from outside South Africa, nationally or provincially.

The large discrepancy between the estimate of total bait usage derived from historic fisherdependant interview data (i.e. roving creel and access point creel surveys) and the estimate from current wholesaler records, indicates that the sampling protocol in the previous studies resulted in data that did not permit accurate estimation of bait usage levels. All these studies solicited information on expenditure on bait per-fisher outing, and not on the quantity of bait used per-fisher outing, and they ignored the practice of anglers retaining unused baits from one outing to the next. It is recommended that future studies on bait usage collect information on the quantity of bait used per interviewee instead of the amount of money spent. Furthermore, the discrepancy between the previous and present studies in terms of bait usage patterns highlights the dynamic nature of fisheries, and emphasises the necessity of using up-to-date information for assessments of current fisheries (Brouwer et al., 1997; Mann et al., 1997; Sauer et al., 1997).

Acknowledgements - The South African Association for Marine Biological Research and Marine and Coastal Management are thanked for providing financial support for the study. All bait retailers and wholesalers who partook willingly in the study are acknowledged for their support. 


\section{REFERENCES}

Augustyn, C.J., Lipinski, M.R., Sauer, \& W.H.H. (1992) Can the loligo squid fishery be managed effectively? A synthesis of research on Loligo vulgaris reynaudii. S. Afr. J. Mar. Sci. 12: 903918.

Beckley, L.E. \& van der Lingen, C.D. (1999) Biology, fishery and management of sardines (Sardinops sagax) in southern African waters. Marine and Freshwater Research 50: 955-978.

Beckley, L.E., Fennessy, S.T. \& Everett, B.I. 2008. Few fish but many fishers: a case study of shorebased recreational angling in a major South African estuarine port. African Journal of Marine Science 30: 11-24.

Begg, G. (1978) The estuaries of Natal. Natal and Regional Planning Report 41.

Branch, G.M., Hauck, M., Siqwana-Ndulo, N. \& Dye, A. H. (2002) Defining fishers in the South African context: subsistence, artisinal and smallscale commercial sectors. S. Afr. J. Mar. Sci. 24: 475-487.

Brouwer, S.L., Mann, B.Q., Lamberth, S.J., Sauer, W.H.H. \& Erasmus, C. (1997) A survey of the South African shore-angling fishery. S. Afr. J. Mar. Sci. 18: 165-77.

Celliers, L., Pradervand, P. \& Moffett, T. (2004) Boat launch sites and the impact on coastal and marine resources along the coast of Kwazulu-Natal, South Africa. In: Green et al. Delivering sustainable coasts: connecting science and policy, Littoral 2004, 20-22 September 2004, Aberdeen Scotland. Conference Proceedings 1: 371-376.

Cochrane, K.L., Butterworth, D.S., De Oliveira, J.A.A . \& Roel, B.A. (1998) Management procedures in a fishery based on highly variable stocks and with conflicting objectives: experiences in the South African pelagic fishery. Rev. Fish. Biol. and Fisheries. 8: 177-214.

De Oliveira, J.A.A., Butterworth, D.S., Roel, B.A., Cochrane, K.L. \& Brown, J.P. (1998) The application of a management procedure to regulate the directed and bycatch fishery of South African sardine Sardinops sagax. S. Afr. J. Mar. Sci. 19: 449-469.

Everett, B.I. 2005. An evaluation of the recreational estuarine line fishery in the Richards Bay harbor. MSc thesis, University of KwaZulu Natal, Durban: 129p.

Everett, B.I. \& Fennessy, S. (2007) Assessment of recreational boat angling in a large estuarineembayment in KwaZulu-Natal, South Africa. Afr. J. Mar. Sci. 29(3): 411-422.
Jairam, S. (2005) The commercial and recreational marine skiboat fisheries in Richards Bay, KwazuluNatal. M.Sc. Dissertation, University of KwazuluNatal, South Africa: 81 p, incl. appendices.

Mann, B.Q., Beckley, L.E. \& van Der Elst, R.P. (1997) An evaluation of linefishery participation and management along the KwaZulu-natal coast. Unpublished Report. S. Afr. Assoc. Mar. Bio. Res. (139): 1-40.

Mann, B.Q., James, N.C. \& Beckley, L.E. (2002) An assessment of the recreational fishery in the St Lucia estuarine system, KwaZulu-Natal, South Africa. S. Afr. J. Mar. Sci. 24: 263-279.

Penney, A.J., Mann-Lang, J.B., van Der Elst, R.P. \& Wilke, C.G. (1999) Long-term trends in catch and effort in the KwaZulu-natal nearshore linefisheries. S. Afr. J. Mar. Sci. 21: 51-76.

Penney, A.J., Griffiths, M.H. \& Attwood, C.G. (1997) Management and monitoring of the South African marine linefishery. Occasional Report. South African Network for Coastal and Oceanic Research. (3): 1-87.

Pradervand, P. 2004. Long-term trends in the shore fishery of the Transkei coast, South Africa. African Zoology 39(2): 247-261.

Pradervand, P. (2005) Assessment of charter boat fishing in Kwazulu-Natal, South Africa. Unpublished Report. S. Afr. Assoc. Mar. Bio. Res. (223): 1-18.

Pradervand, P., Mann, B.Q. \& Bellis, M. 2007, Longterm trends in the competitive shore fishery along the KwaZulu-Natal coast. African Zoology 42(2): 216-236.

Pradervand, P. \& Govender, R. (1999) Monitoring of the Kwazulu-Natal linefishery - The National Marine Linefish System. In: Mann, BQ., Ed. Proceedings of the third southern African marine linefish symposium, 28 April - 1 May 1999, Arniston, Western Cape. Occasional Report. South African Network for Coastal and Oceanic Research. (5): 43-46.

Pradervand, P. \& Baird, D. (2002) A preliminary assessment of the recreational linefishery in selected Eastern Cape estuaries: trends in catches and effort. S. Afr. J. Mar. Sci. 24: 87-101.

Pradervand, P., Beckley, L.E., Mann, B.Q. \& Radebe, P.V. (2003) Assessment of the linefishery in two urban estuarine systems in Kwazulu-Natal, South Africa. S. Afr. J. Mar. Sci. 25: 111-30.

Pradervand, P., Khumalo, M., Kunene, P. \& Mann, B.Q. (2006) Boat launch site monitoring system: 2005 Annual Report. Data Report. S. Afr. Assoc. Mar. Bio. Res. (2006/1): 1-15.

Roel, B. A. \& Armstrong, M.J. (1991) The round herring Etrumeus whiteheadi, an abundant, 
underexploited clupeoid species off the coast of southern Africa. S. Afr. J. Mar. Sci. 11: 267-87.

Sauer, W.H.H., Penney, A.J., Erasmus, C., Mann, B.Q., Brouwer, S.L., Lamberth, S.J. \& Stewart, T.J. (1997) An evaluation of attitudes and responses to monitoring and management measures for the South African boat-based linefishery. S. Afr. J. Mar. Sci. 8: $147-64$

Sauer, W.H.H., Hecht, T., Britz, P.J. \& Mather, D. (2003) An economic and sectoral study of the South African fishing industry. Volume 2: Fishery profiles. Report prepared for Marine and Coastal Management. Rhodes University.

Tomalin, B.J., Robertson, W.D. \& Fielding, P.J. (1993) The great bait debate. In: Beckley, L.E.
\& van der Elst, R.P. Fish, fishers and fisheries: proceedings of the second South African Marine Linefish Symposium, Durban, 23-24 October 1992. Special Publication. S. Afr. Assoc. Mar.Bio. Res. (2): 160-164.

Tomalin, B.J., Beckley, L.E., Fennessy, S.T., Fielding, P.J., Robertson, W.D., Tomalin, B.J. \& van der Elst, R.P. (1996) Informal fisheries on the east coast of South Africa (HSRC project). Unpublished Report. S. Afr. Assoc. Mar. Bio. Res. (133): 1-35.

van der Elst ,R.P. (1989) Marine recreational angling in South Africa. In: Payne AIL, Crawford RJM (eds) Oceans of Life off Southern Africa. Vlaeberg, Cape Town, pp 164-176. 
